\title{
Horoshko V.
}

\section{CONTROL OPTIMIZATION OF ELECTROMECHANICAL SYSTEMS BY FRACTIONAL-INTEGRAL CONTROLLERS}

Об'єктом дослідження в роботі є електромеханічні системи, характерною особливістю яких є наявність суттєвої степеневої залежності в математичному описі. Через це виникають проблеми при виборі структури та параметрів регуляторів. Зокрема, в двигуні постійного струму з послідовним збудженням, вентильно-реактивному двигуні та електромагнітних гальмах може відбуватися насичення магнітної системи в статичних і динамічних режимах. Застосований в роботі апарат дробово-інтегрального числення дозволяє такі нелінійні об'єкти описати з високою точністю лінійними передавальними функціями дробового порядку. Так, при апроксимацї якірного ланщюга двигуна постійного струму з послідовним збудженням передавальною функцією дробового порядку отримано найменшу середньоквадратичну похибку. Комбінація звичайного PID-регулятора с дробово-інтегральними складовими порядку 0,35 та 1,35 забезпечує найкращу якість перехідного процесу - струм досягає заданого значення максимально швидко без перерегулювання. По-друге, вентильно-реактивний двигун, в моделі якого необхідно враховувати степеневі залежності, при описі перехідних прочесів швидкості при стрибку напруги апроксимовано аперіодичною функиією порядку 0,7. 3 сімейства досліджених регуляторів традиційний РІ-регулятор з додатковими дробово-інтегральними складовими порядку 0,7 та 1,7 забезпечив астатизм контуру швидкості порядку 1,7 та найменше перерегулювання. По-третє, електромагнітні гальма ведучих коліс автомобіля, що використовуються для налаштування двигуна внутрішнього згоряння, також після тестування найбільш точно описані передавальною функиією дробового порядку. За допомогою PIDIr ${ }^{\mu}-$ регулятора, що забезпечив астатизм замкненого контуру порядку 1,63, досягнуто стабілізачію швидкості обертання двох коліс без протифазних коливань і точне відпрацювання трикутної тахограми. Таким чином, завдяки апарату дробово-інтегрального числення забезпечується більш точна ідентифікачія параметрів об'єкта, математичний опис зводиться до лінійних передавальних функиій дробового порядку. А в замкнених системах можна забезпечити астатизм дробового порядку 1,3-1,7 та домогтися кращої якості перехідних процесів, ніж при використанні класичних методів.

Ключові слова: дробово-інтегральне числення, дробові інтегрально-диференційні регулятори, замкнута система управління, електромеханічна система.

\section{Introduction}

The beginning of the development of fractional calculus is considered to be 1695, when Leibniz in a letter to Francois L'Hospital discussed the differentiation of the order 1/2 [1]. More than 300 years have passed since then, mathematicians have conducted numerous studies in this field. But a new surge of interest in it is noticeable in recent decades. This is primarily due to the fact that differential equations with fractional order made it possible to describe some physical processes with greater accuracy than integer ones [2, 3]. Also, the computing capabilities of modern single-chip processors already correspond to the complexity of calculating fractional integrals and derivatives in real time. Therefore, ways of applying this mathematical apparatus in technical systems, in particular in acoustics, electronics, and thermodynamics, have opened $[4,5]$. In controlled systems, $P \Gamma^{\gamma} D^{\mu}$ controllers are used that can improve the quality of transients in comparison with classical integer PID controllers, especially in nonlinear systems $[6,7]$.
The aim of this research is to study the possibility of using the apparatus of fractional integral calculus in electromechanics to optimize transient and steady-state processes. DC motor with series excitation, switched reluctance motor and an induction brake are considered as objects of research.

\section{Methods of research}

The study of each of the listed objects was carried out according to the generally accepted methodology. Based on the testing of objects by supplying standard signals, identification of model parameters was carried out with the subsequent synthesis of optimal controllers and verification of closed systems. However, at the identification stage, in addition to the generally accepted ones, models are considered that include fractional differential equations. This choice is due to the fact that the apparatus of fractional integral numbering is based on power functions, and in the considered electromechanical objects the magnetization 
curve is also close to the power function. It is precisely this which suggests that controllers with integral and differential components of non-integer order can provide the best dynamic and static indicators of systems.

\section{Research results and discussion}

Transients significantly differ from solutions of differential equations of the first or second order in DC motor with series excitation at a current in the armature circuit above the rated value [8].

The smallest standard error is provided when using the following mathematical model:

$$
W_{c o}=\frac{K}{a_{1} s^{1+\mu}+a_{0} s^{\mu}+1},
$$

where for the studied motor with a power of $450 \mathrm{~W}$ received $K=0.193$ - gain coefficient; $\mu=0.35$ - indicator of the fractional differential equation; $a_{1}=0.0062, a_{0}=0.127-$ parameters equivalent to the time constants in degrees $1+\mu$ and $\mu$, respectively.

Accordingly, to ensure optimum tuning with a given integer or fractional orders of astatism, $D^{\mu} I^{\gamma} I^{-}, P I^{\gamma} I^{-}$, PIDI $T^{\mu}$ controllers are required.

In the course of experimental studies, the best quality of the transient process was obtained with the PIDIr ${ }^{\mu}$ controller (Fig. 1, $a$ ). In this case, the current reaches the reference as quickly as possible and without overshoot.

It turned out that such settings are effective even with reference signals half the maximum, as well as with stepwise change of reference (Fig. 1, b, c). It can be seen that the quality indicators of the system remain unchanged and correspond to the desired settings.

Another electric machine, in the description of which it is necessary to take into account power dependencies, is a switched reluctance motor. To identify a closed speed loop, a fractionally aperiodic transfer function of the following form was also chosen [9]:

$$
W_{c o 1}=\frac{K}{a_{0} s^{\mu}+1} .
$$

The approximation results are illustrated in Fig. 2. As can be seen, at different applied voltages, the nature of the transition process changes, but the use of the fractional transfer function (2) provides the smallest deviation. And this also allows for the synthesis of controllers to abandon the complex motor model described by a system of nonlinear differential equations.

Accordingly, the adjustment of the closed loop is greatly simplified - the modular optimum provides the $I I^{\gamma}$ controller, and the fractional order of astaticism 1.7 is achieved using the PIIr $\mu^{\mu}$ controller.

Fig. 3 shows the simulation results of transients in the speed control loop of a switched reluctance motor. In Fig. 3, $a$, the graphs of transients during the jump of the reference are shown, in Fig. 3, $b$ - with a step change in the reference signal. In all cases, a system with a fractional order of astaticism has the best dynamic characteristics.

A similar approach was used for the synthesis of the electromagnetic retarders control system of the driving wheels of a car on a stand for tuning and measur- ing the power (torque) of an internal combustion engine (ICE) [10].

According to the experimental data obtained, the control object is approximated with an error of about $1 \%$ by the following transfer functions:
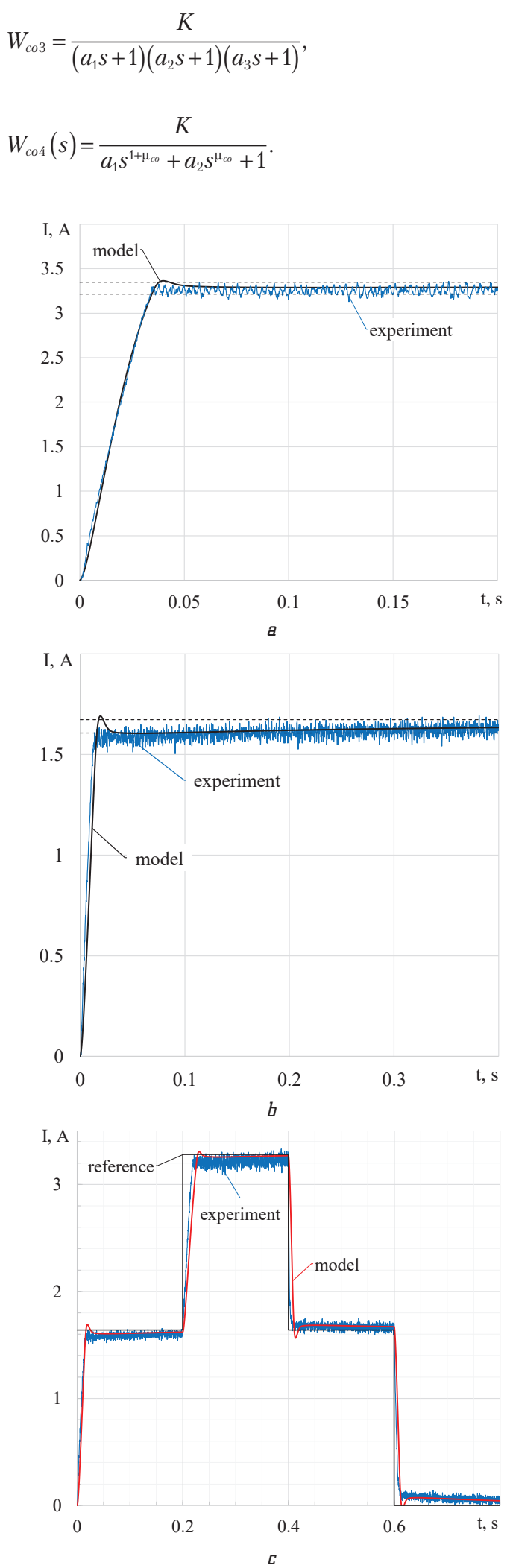

Fig. 1. Current transients in the $\mathrm{DC}$ motor with series excitation: $a$ - with a reference signal of $3.2 \mathrm{~A} ; b$ - with a reference signal of $1.6 \mathrm{~A}$; $c$ - with step change of the reference signal 


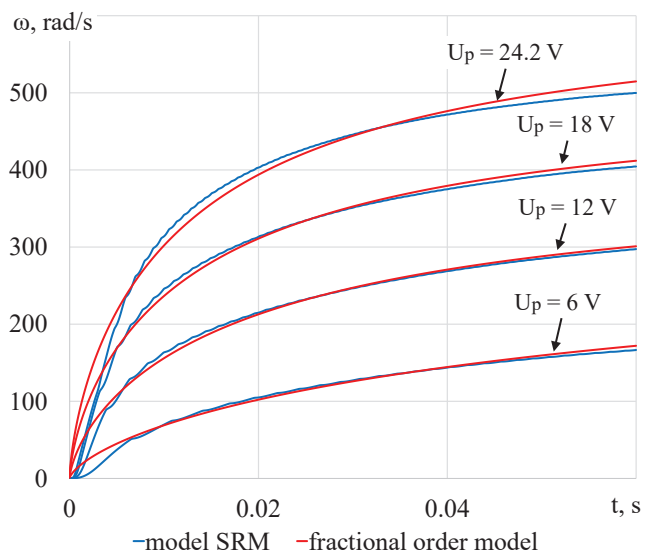

Fig. 2. Graphs of speed transients in an open system at various voltages
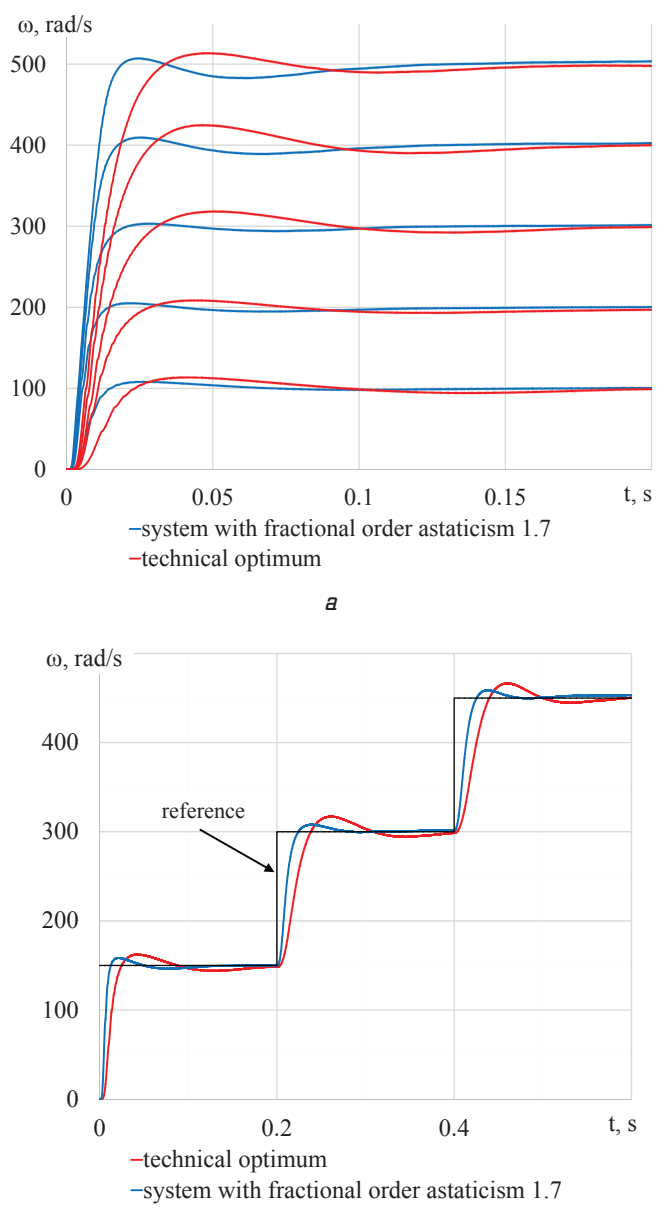

$b$

Fig. 3. Graphs of transient processes of the speed of a switched reluctance motor: $a-$ in a closed system with reference jumps; $b$ - with a step change in the reference signal

Using the transfer function (3), the coefficients for the PID controller were found, and according to (4), two types of fractional-integral controllers were synthesized: $D^{\gamma} I^{\mu} I$, which provides tuning to the modular optimum, and $P I D T^{\mu} T^{\mu}$, which allows obtaining the fractional astaticism order 1.63 .

When conducting experimental studies, transient graphs were obtained with stabilization of the speed of the semiaxles of the car (Fig. 4, a). The PID controller provided the best performance $(2.55 \mathrm{~s})$, but with the greatest overshoot $\delta_{1}=27.6 \%$. With the $D^{\gamma} I^{\mu} I$ controller, the overshoot was $\delta_{2}=16.3 \%$, and the duration of the transient process was $4.42 \mathrm{~s}$. The smallest overshoot was obtained with the PIDIr ${ }^{\mu}$ controller $-\delta_{3}=3.3 \%$ for a duration of $3.8 \mathrm{~s}$.

An important step in checking the results of engine settings is to measure the power and maximum torque when forming a triangular tachogram.

The results of such a test with the fastest $(P I D)$ and most accurate $\left(P I D \Gamma^{\gamma} \Gamma^{\mu}\right)$ controllers are shown in Fig. $4, b$.
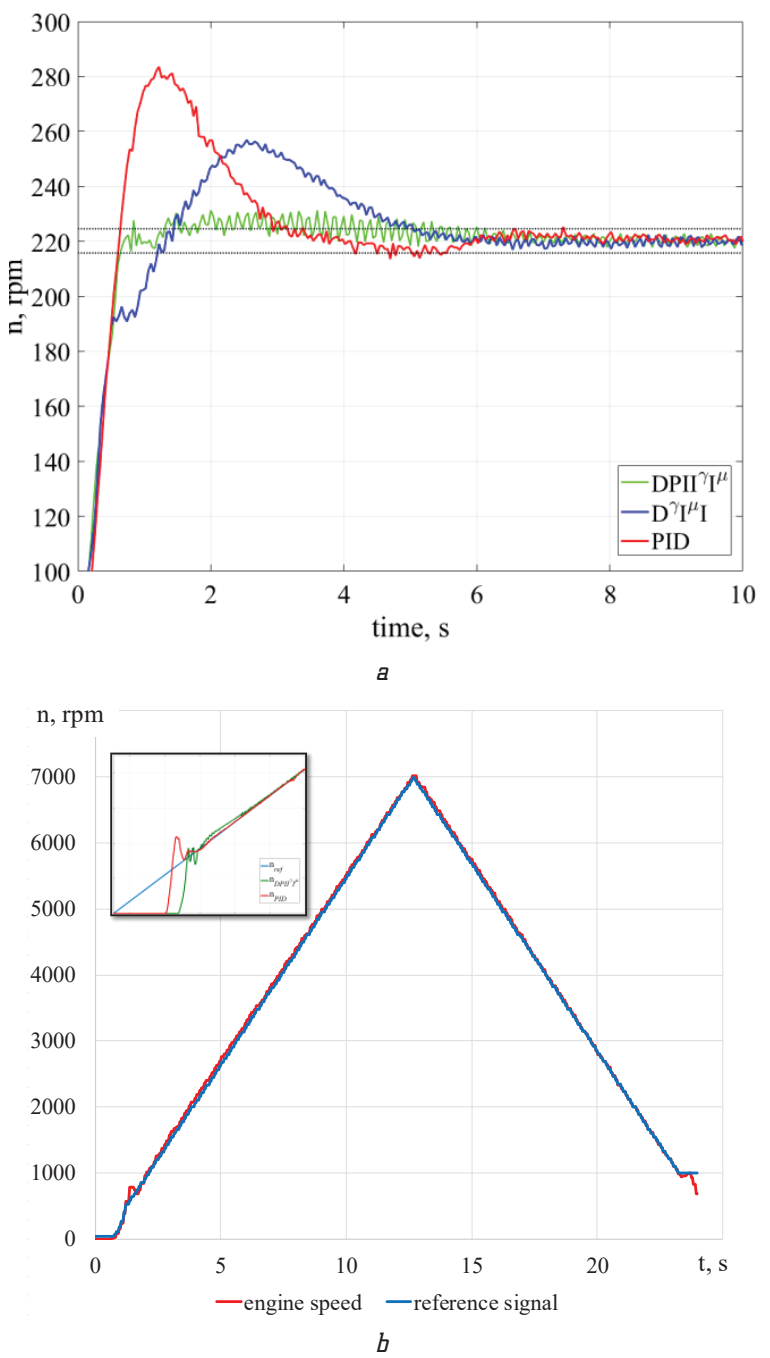

Fig. 4. Transient graphs of the average speed of the semi-axles of the car: $a$ - during stabilization of speed; $b$ - during measuring power

Both controllers provide stabilization of speed in the entire range of power measurement, but less overshoot and oscillation at the beginning of acceleration (the initial sections of transient processes with various controllers are compared in the upper left in Fig. 4, b). This allowed to make the final decision on choosing a control system block diagram in favor of the PIDI ${ }^{\mu}{ }^{\mu}$ controller.

\section{Conclusions}

Thus, the use of the fractional integral calculus for three types of nonlinear electromechanical objects, in the 
description of which there are power functions, allowed us to obtain the following:

1. A more accurate identification of the parameters at which the smallest discrepancy between the calculated and experimental data is achieved when testing open systems.

2. A simplified mathematical description due to the use of fractional-order linear transfer functions in models.

3. The best dynamic and static indicators, especially when using fractional-integral controllers, providing a fractional (1.5-1.7) order of closed loop astaticism.

\section{References}

1. Joseph, K. M. (2009). Fractional calculus: Definitions and Applications. Masters Theses \& Spesialist Projects. Available at: https://digitalcommons.wku.edu/theses/115/

2. Uchaikin, V. V. (2013). Fractional Derivatives for Physicists and Engineers. Berlin Heidelberg: Higher Education Press, Beijing and Springer-Verlag, 385. doi: http://doi.org/10.1007/978-3642-33911-0

3. Tarasov, V. E. (2010). Fractional Dynamics. Applications of Fractional Calculus to Dynamics of Particles, Fields and Media. Berlin, Heidelberg: Higher Education Press, Beijing and Springer-Verlag, 505.

4. Oldham, K. B., Spanier, J. (1974). The Fractional Calculus: Theory and Applications of Differentiation and Integration to Arbitrary Order. New York: Academic Press, 322.
5. Hilfer, R. (2000). Applications of Fractional Calculus in Physics. River Edge: World Scientific, 472. doi: http://doi.org/10.1142/3779

6. Petrás, I. (2009). Fractional - order feedback control of a DC motor. Journal of Electrical Engineering, 60 (3), 117-128. Available at: http://iris.elf.stuba.sk/jeeec/data/pdf/3 109-01.pdf

7. Tytiuk, V., Chornyi, O., Baranovskaya, M., Serhiienko, S., Zachepa, I., Tsvirkun, L. et. al. (2019). Synthesis of a fractional-order PI $\lambda$ D $\mu$-controller for a closed system of switched reluctance motor control. Eastern-European Journal of Enterprise Technologies, 2 (2 (98)), 35-42. doi: http://doi.org/10.15587/17294061.2019 .160946

8. Busher, V., Melnikova, L., Horoshko, V. (2019). Synthesis and implementation of fractional-order controllers in a current curcuit of the motor with series excitation. Eastern-European Journal of Enterprise Technologies, 2 (2 (98)), 63-72. doi: http:// doi.org/10.15587/1729-4061.2019.161352

9. Busher, V. V., Goroshko, V. V. (2019). Fractional IntegralDifferentiating Control in Speed Loop of Switched Reluctance Motor. Problemele energeticii regionale, 1 (2 (42)), 46-54. doi: http://doi.org/10.5281/zenodo.3239166

10. Busher, V., Horoshko, V. (2019). Dual Electromagnetic Retarder Control System for Tuning Internal Combustion Engines. 2019 IEEE International Conference on Modern Electrical and Energy Systems (MEES). doi: http://doi.org/10.1109/mees.2019.8896526

Horoshko Vasiliy, Postgraduate Student, Assistant, Department of Electromechanical Engineering, Odessa National Polytechnic University,Ukraine, e-mail: vas.goroshko@gmail.com, ORCID: http:// orcid.org/0000-0002-7265-2513 